\title{
ANALYSES OF BLOOD OF INSANE PATIENTS
}

PAUL G. WESTON, M.D. WARREN, PA.

Ishida ${ }^{1}$ reported a deficiency of chlorin in the blood of dementia praecox patients and suggested the use of sodium chlorid solution intravenously in the treatment of this condition. He estimated the chlorin values of the blood of five untreated cases of dementia praecox, and the amounts varied from 0.199 to 0.220 per cent. The analyses were made by Professor Horinchi by the Vollhard-Salkowski method. Guthrie ${ }^{2}$ published a report of the results of the treatment of fifteen cases of dementia praecox based on chemical analyses of the blood and reported a deficiency of chlorin, but the quantities found and the methods of analysis are not mentioned. Rappleye ${ }^{3}$ stated that in some cases of catatonia he found a deficiency of chlorin. Miller ${ }^{4}$ quoted analyses made by Weston of the blood of ten cases of dementia praecox, the chlorin being normal in each case, and he stated that "there was no deficiency of chlorin in the blood . . . in any of fifteen other cases examined." Rappleye ${ }^{3}$ studied the blood urea in catatonic patients at from three to seven day intervals before, during and after the catatonic state. He found that a marked drop, about 50 per cent., in the urea nitrogen occurred early and rapidly in catatonia.

The figures of Ishida, Rappleye and Weston do not agree. In Rappleye's cases the urea was determined when catatonia was present, as well as when it was not. Weston's figures are from one analysis made when the patient was not in the catatonic state.

Since there is some disagreement in the published estimates of chlorin and urea nitrogen, the accompanying tables may be of interest. They represent analyses of the blood of thirty insane patients, selected cases of dementia praecox, epilepsy and manic-depressive insanity. The analyses were made a little more than two years ago. All the patients were living under practically identical conditions and had substantially the same diet. As the blood was collected before breakfast, twelve hours after the preceding meal, the effect of diet may be disregarded. Care was taken to use clear cases, and in each case selected there was unanimity of opinion when the patient was pre-

1. Ishida, N.: Am. J. Insan, 73:541 (Jan.) 1917.

2. Guthrie: Dementia Praecox Studies 1:61, 1918.

3. Rappleye, W, C.: J. Nerv. \& Ment. Dis. 49:130 (Feb.) 1919.

4. Miller, W. C.: Arch. Neurol. \& Psychiat. 1:313 (March) 1919. 
sented at a staff meeting for diagnosis. The Wassermann reaction in all cases was negative (cholesterolized human heart antigen), and no abnormal substances were found in the urine of any patient.

TABle 1.-Blood Analyses of Ten Cases of Manic Depressive Insanity

\begin{tabular}{|c|c|c|c|c|c|c|c|c|c|c|c|}
\hline \multirow[b]{2}{*}{ 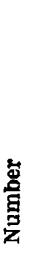 } & \multirow[b]{2}{*}{$\stackrel{\Delta}{\square}$} & \multirow[b]{2}{*}{ 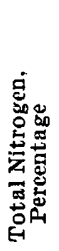 } & \multicolumn{8}{|c|}{ Milligrams per Hundred C.c. of Blood } & \multirow[b]{2}{*}{ Remarks } \\
\hline & & & 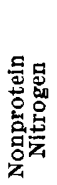 & $\begin{array}{l}\frac{5}{0} \\
\frac{0}{4} \\
\stackrel{\varrho}{0}\end{array}$ & 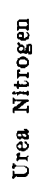 & 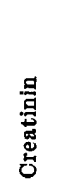 & 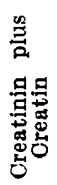 & 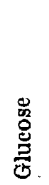 & 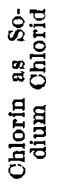 & $\underset{\text { 总 }}{\stackrel{\Xi}{\Xi}}$ & \\
\hline $\begin{array}{r}1 \\
2 \\
3 \\
4 \\
5 \\
6 \\
7 \\
8 \\
9 \\
10\end{array}$ & $\begin{array}{l}33 \\
40 \\
38 \\
29 \\
40 \\
36 \\
29 \\
37 \\
40 \\
44\end{array}$ & $\begin{array}{l}3.85 \\
3.45 \\
\mathbf{3 . 6 0} \\
\mathbf{3 . 5 5} \\
\mathbf{3 . 2 0} \\
\mathbf{3 . 4 5} \\
\mathbf{3 . 5 0} \\
\mathbf{3 . 7 0} \\
\mathbf{3 . 6 0} \\
\mathbf{3 . 7 5}\end{array}$ & $\begin{array}{l}36 \\
33 \\
34 \\
33 \\
31 \\
33 \\
33 \\
35 \\
34 \\
32\end{array}$ & $\begin{array}{l}2.12 \\
2.60 \\
1.95 \\
2.20 \\
2.40 \\
1.80 \\
2.20 \\
2.10 \\
2.30 \\
2.75\end{array}$ & $\begin{array}{l}24 \\
16 \\
22 \\
20 \\
20 \\
24 \\
27 \\
24 \\
22 \\
20\end{array}$ & $\begin{array}{l}2.15 \\
1.90 \\
2.10 \\
1.85 \\
1.75 \\
1.60 \\
2.00 \\
2.10 \\
1.90 \\
1.80\end{array}$ & $\begin{array}{l}8.90 \\
7.60 \\
8.40 \\
7.20 \\
7.60 \\
7.40 \\
8.00 \\
7.90 \\
8.00 \\
7.00\end{array}$ & $\begin{array}{r}90 \\
90 \\
100 \\
110 \\
120 \\
90 \\
85 \\
90 \\
90 \\
110\end{array}$ & $\begin{array}{l}480 \\
490 \\
500 \\
510 \\
506 \\
490 \\
484 \\
480 \\
490 \\
510\end{array}$ & $\begin{array}{l}8.0 \\
7.8 \\
7.0 \\
9.1 \\
8.8 \\
7.7 \\
8.8 \\
8.4 \\
8.0 \\
7.8\end{array}$ & $\begin{array}{l}\text { Hypomanic } \\
\text { Hypomanie } \\
\text { Hypomanic } \\
\text { Depressed } \\
\text { Depressed } \\
\text { Depressed } \\
\text { Depressed } \\
\text { Interval } \\
\text { Interval } \\
\text { Interval }\end{array}$ \\
\hline
\end{tabular}

Table 2.-Blood Analyses of Ten Epilepsy Cases

\begin{tabular}{|c|c|c|c|c|c|c|c|c|c|c|c|}
\hline \multirow[b]{2}{*}{$\begin{array}{l}\text { 岁 } \\
\text { 㤩 } \\
\text { 穵 }\end{array}$} & \multirow[b]{2}{*}{$\stackrel{50}{0}$} & \multirow[b]{2}{*}{ 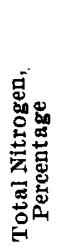 } & \multicolumn{8}{|c|}{ Milligrams per Hundred C.c. of Blood } & \multirow[b]{2}{*}{ Remarks } \\
\hline & & & 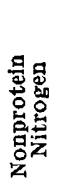 & 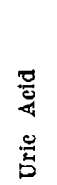 & 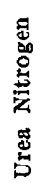 & 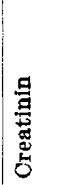 & 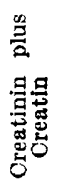 & 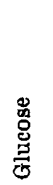 & 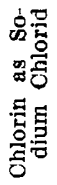 & 䄒 & \\
\hline $\begin{array}{l}11 \\
12 \\
13 \\
14 \\
15 \\
16 \\
17 \\
18 \\
19 \\
20\end{array}$ & $\begin{array}{l}35 \\
32 \\
28 \\
31 \\
31 \\
35 \\
40 \\
37 \\
22 \\
28\end{array}$ & $\begin{array}{l}3.16 \\
3.52 \\
3.48 \\
3.21 \\
3.75 \\
3.64 \\
3.80 \\
3.72 \\
3.69 \\
3.71\end{array}$ & $\begin{array}{l}32 \\
36 \\
34 \\
37 \\
36 \\
32 \\
33 \\
34 \\
32 \\
38\end{array}$ & $\begin{array}{l}1.90 \\
1.85 \\
2.20 \\
2.16 \\
2.30 \\
2.00 \\
1.85 \\
1.90 \\
1.76 \\
2.00\end{array}$ & $\begin{array}{l}18 \\
20 \\
22 \\
20 \\
21 \\
22 \\
24 \\
20 \\
21 \\
24\end{array}$ & $\begin{array}{l}1.25 \\
2.25 \\
2.31 \\
1.95 \\
1.70 \\
1.67 \\
2.00 \\
2.20 \\
2.12 \\
2.10\end{array}$ & $\begin{array}{l}6.20 \\
8.20 \\
9.40 \\
7.60 \\
8.40 \\
7.80 \\
8.10 \\
8.20 \\
8.00 \\
7.95\end{array}$ & $\begin{array}{r}100 \\
90 \\
110 \\
105 \\
121 \\
95 \\
90 \\
110 \\
120 \\
100\end{array}$ & $\begin{array}{l}480 \\
495 \\
506 \\
512 \\
500 \\
484 \\
510 \\
490 \\
486 \\
495\end{array}$ & $\begin{aligned} 7.8 \\
7.8 \\
\cdot 8.8 \\
8.0 \\
7.7 \\
7.0 \\
7.5 \\
6.9 \\
7.6 \\
7.9\end{aligned}$ & $\begin{array}{l}\text { Grand mal } \\
\text { Grand mal } \\
\text { Grand } \mathrm{mal} \\
\text { Grand } \mathrm{mal} \\
\text { Grand } \mathrm{mal} \\
\text { Grand mal } \\
\text { Grand mal } \\
\text { Grand mal } \\
\text { Grand mal } \\
\text { Grand mal }\end{array}$ \\
\hline
\end{tabular}

No seizures were recorded for forty-elght hours preceding the analyses.

TECHNIC

Blood was first drawn for the usual routine Wassermann reaction, and then at least 30 c.c. were collected in a tube containing $0.45 \mathrm{gm}$. of powdered, calcium-free sodium citrate. Oxalate was not used because calcium determinations were to be made with the blood. Analysis was begun at once, and four specimens were examined at the same time, this being as large a number as could be handled without an assistant.

The blood was divided as follows:

Ten c.c. of blood were added to 30 c.c. of 6.25 per cent. trichloracetic acid solution (freshly prepared) in a 50 c.c. volumetric flask. 
The mixture was well shaken, distilled water was added until the solution reached the mark, and the flask was set aside for one hour. At the end of this time, the contents were poured into a tube and centrifugalized. The supernatant fluid was pipetted off or filtered through a double-washed filter paper and used for the determination of chorids by titration with potassium thiocyanate, nonprotein nitrogen by the method of Folin and Denis, ${ }^{5}$ and calcium by Lyman's method. ${ }^{\circ}$ The use of trichloracetic acid did not affect the chlorin values. Blanks were run each day for calcium and chlorin.

Table 3.-Blood Analyses of Ten Dementia Praecox Cases

\begin{tabular}{|c|c|c|c|c|c|c|c|c|c|c|c|}
\hline \multirow[b]{2}{*}{$\frac{\mathrm{L}}{\mathrm{E}}$} & \multirow[b]{2}{*}{ 喿 } & \multirow[b]{2}{*}{ 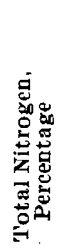 } & \multicolumn{8}{|c|}{ Milligrams per Hundred C.c. of Blood } & \multirow[b]{2}{*}{ Remarks } \\
\hline & & & 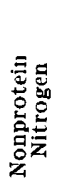 & $\begin{array}{l}\frac{0}{0} \\
\frac{0}{4} \\
\frac{0}{2}\end{array}$ & 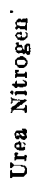 & $\begin{array}{l}\text { 品 } \\
\text { 芯 } \\
\text { 品 }\end{array}$ & 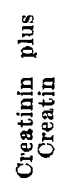 & 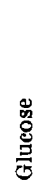 & 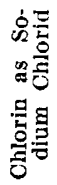 & 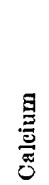 & \\
\hline $\begin{array}{l}21 \\
22 \\
23 \\
24 \\
25 \\
26 \\
27 \\
28 \\
29 \\
30\end{array}$ & $\begin{array}{l}21 \\
18 \\
28 \\
21 \\
36 \\
27 \\
23 \\
26 \\
29 \\
32\end{array}$ & $\begin{array}{l}3.52 \\
3.75 \\
3.44 \\
3.26 \\
3.64 \\
4.00 \\
4.00 \\
3.80 \\
3.25 \\
3.19\end{array}$ & $\begin{array}{l}31 \\
33 \\
34 \\
33 \\
31 \\
39 \\
40 \\
33 \\
33 \\
33\end{array}$ & $\begin{array}{l}2.40 \\
2.60 \\
1.50 \\
1.90 \\
2.00 \\
2.60 \\
2.70 \\
1.90 \\
2.00 \\
1.80\end{array}$ & $\begin{array}{l}16 \\
17 \\
22 \\
19 \\
16 \\
22 \\
18 \\
16 \\
16 \\
18\end{array}$ & $\begin{array}{l}2.00 \\
1.82 \\
1.90 \\
2.16 \\
2.20 \\
1.85 \\
2.10 \\
1.90 \\
1.70 \\
2.15\end{array}$ & $\begin{array}{r}8.10 \\
7.90 \\
8.00 \\
7.20 \\
10.00 \\
9.40 \\
8.10 \\
8.66 \\
9.00 \\
9.21\end{array}$ & $\begin{array}{l}105 \\
101 \\
106 \\
111 \\
120 \\
112 \\
105 \\
124 \\
117 \\
109\end{array}$ & $\begin{array}{l}515 \\
510 \\
510 \\
494 \\
491 \\
506 \\
512 \\
500 \\
500 \\
515\end{array}$ & $\begin{array}{l}5.7 \\
5.5 \\
6.2 \\
8.0 \\
8.0 \\
7.8 \\
7.8 \\
6.0 \\
8.0 \\
6.5\end{array}$ & $\begin{array}{l}\text { Hebephrenic } \\
\text { Hebephrenic } \\
\text { Hebephrenic } \\
\text { Catatonic } \\
\text { Catatonic } \\
\text { Catatonic } \\
\text { Catatonic } \\
\text { Paranoid } \\
\text { Paranoid } \\
\text { Paranoid }\end{array}$ \\
\hline
\end{tabular}

Blood was not drawn during catatonia.

TABLE 4.-NoRMal. Valdes*

\begin{tabular}{|c|c|c|c|}
\hline & \multicolumn{3}{|c|}{ Author } \\
\hline & $\begin{array}{c}\text { Gettler and } \\
\text { Baker }\end{array}$ & Folin and & $\begin{array}{l}\text { Myers and } \\
\text { Fine }^{20}\end{array}$ \\
\hline 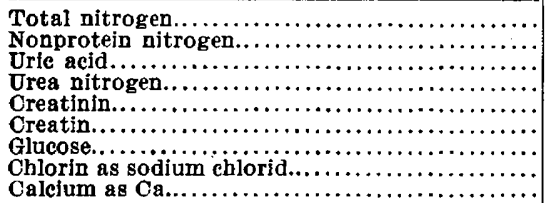 & $\begin{aligned} & 3.7 \\
30 & -45 \\
1 & -3.5 \\
15 & -25 \\
0.1 & -0.5 \\
3 & -6.5 \\
50 & -120 \\
450 & -500 \\
5.2 & -9.6^{18}\end{aligned}$ & $\begin{array}{c}\ldots 2.37 \\
22-37 \\
0.7-3.7 \\
12-27 \\
1.1-1.4 \\
5.2-8.1 \\
90-100^{14} \\
490^{16}\end{array}$ & $\begin{array}{c}3.0 \\
25-30 \\
1-2 \\
12-15 \\
1-2 \\
5-10 \\
90=130^{15} \\
457^{17}\end{array}$ \\
\hline
\end{tabular}

* Data for this table were taken from the paper of Gettler and Baker. Total nitrogen is expressed in per cent. All other values are in terms of milligrams per hundred c.c. of blood. The figures for calcium are from Lyman's paper.

Five c.c. of blood were used for the determination of creatin, creatinin and glucose by the methods of Myers and Fine. ${ }^{7}$

5. Folin, O., and Denis, W.: J. Biol. Chem. 26:473 (Sept.) 1916.

6. Lyman, H.: J. Biol. Chem. 29:169 (March) 1917.

7. Myers, V. C., and Fine, M. S.: Chemical Composition of the Blood in Health and Disease, Post-Graduate 30:39, 1915. 
One c.c. of blood was used for the urea determination, and one c.c. for control. Dunning urease tablets were used for fermentation, and the ammonia was determined by Nesslerization after aeration.

One c.c. of blood was added to 99 c.c. of ammonia-free distilled water and 1 c.c. of the dilution used for the determination of total nitrogen by the method of Folin and Denis. ${ }^{5}$

The remaining 10 or more cubic centimeters were used for the determination of uric acid by the method of Myers and Fine. ${ }^{7}$

The Kober colorimeter and nephelometer were used throughout and all glassware was certified.

The creatinin values recorded in the tables are far above the normals given by Gettler and Baker, ${ }^{8}$ and Gettler. ${ }^{9}$ For the method employed, however, the values are not above normal. The picric acid used answered the requirements laid down by Folin and Doisy, ${ }^{10}$ and the sodium citrate, in the quantities used, had no bleaching effect.

Cholesterol is not included in the tables. Several hundred estimations have been made, but the results did not vary from the normal. Some of the results have already been published. ${ }^{11}$

The relation of the sugar content of the blood and spinal fluid was reported some years ago. ${ }^{12}$ In sixty-five cases, the spinal fluid sugar averaged 60 per cent. of the blood sugar. Recently, Myers and Fine ${ }^{13}$ found in fifteen cases that the spinal fluid sugar averaged 57 per cent. of that in the blood.

\section{SUMMARY}

The blood of epileptic, dementia praecox and manic-depressive patients shows no deviation from the normal content of total nitrogen, nonprotein nitrogen, uric acid, urea, creatinin, creatin, glucose, chlorin or calcium. ${ }^{14}$

8. Gettler, A. O., and Baker, W.: J. Biol. Chem. 25:211 (June) 1916.

9. Gettler, A. O.: J. Biol. Chem. 29:47 (Feb.) 1917.

10. Folin, O., and Doisy; E. A.: J. Biol. Chem. 28:349 (Jan.) 1917.

11. Weston and Kent: J. M. Research 26:531, 1912.

12. Weston, P. G.: J. M. Research 35:199 (Nov.) 1916.

13. Myers, V. C., and Fine, M. S.: J. Biol. Chem. 37:239 (Feb.) 1919.

14. In addition to the references given, the following papers may be of interest: Lewis and Benedict: J. Biol. Chem. 20:61, 1915; Michaelis: Biochem. Ztschr. 59:211, 1916; McLean and Vanslyke: J. Biol. Chem. 21:361, 1915; Rogee and Fritsch: Biochem. Ztschr. 54:53, 1913; Lyman, H.: J. Biol. Chem. 30:1 (May) 1917; Folin and Denis: J. Biol. Chem. 14:29, 1913; Myers, V. C., and Fine, M. S.: Post-Graduate, New York 29:473, 1914. 